\title{
MTHFR genetic polymorphism and the risk of intrauterine fetal death in Polish women
}

\author{
Hubert Wolski ${ }^{1,2}$, Grazyna Kurzawinska 2, 3, Krzysztof Drews ${ }^{2,3}$, Magdalena Barlik 2, 3 , \\ Przemyslaw Kadziolka ${ }^{4}$, Zbyszko Malewski ${ }^{2}$, Paula Mikolajska-Ptas', \\ Michal Bylewski ${ }^{1}$, Agnieszka Seremak-Mrozikiewicz ${ }^{2,3}$ \\ ${ }^{1}$ Division of Gynecology and Obstetrics, Podhale Multidisciplinary Hospital, Nowy Targ, Poland \\ ${ }^{2}$ Division of Perinatology and Women's Diseases, Poznan University of Medical Sciences, Poland \\ ${ }^{3}$ Laboratory of Molecular Biology in Division of Perinatology and Women's Diseases, Poznan University of Medical Sciences, Poland \\ ${ }^{4}$ Department of Maternal and Child Health, Poznan University of Medical Sciences, Poland
}

\begin{abstract}
Objectives: To evaluate the role of MTHFR genetic variants in the etiology of intrauterine fetal death in the second part of pregnancy at women from Polish population.

Material and methods: A case-control study was performed on a 76 women with a positive history of at least one intrauterine fetal death after 22 gestational week and 400 healthy controls. The MTHFR genotyping for polymorphic sites $667 C>T, 1298 \mathrm{~A}>\mathrm{C}, 1793 \mathrm{G}>\mathrm{A}$ was determined by polymerase chain reaction/restriction fragment length polymorphism (PCR/RFLP) method.

Results: For 1298A > C polymorphism, no statistically significant higher frequency of AA vs. AC+CC genotype was observed in the IUFD group $67.1 \%$ vs. $55.2 \%$ in the control group ( $\left.O R=0.61, p=0.05, p_{\text {corr }}=0.15\right)$. We observed overrepresentation of three-locus haplotype CCG ( $\left.p=0.20 ; p_{\text {corr }}=0.56\right)$ and two-locus haplotype CC $\left(p=0.17 ; p_{\text {corr }}=0.48\right)$ in the IUFD group compared to controls.

Conclusions: There was no observed relationships in genotype frequency of MTHFR 677C $>$ T and 1793G $>$ A variants, however 1298A > C showed a slightly higher but statistically insignificant prevalence in IUFD compared to the controls in Polish population. Further studies on a larger population are needed.
\end{abstract}

Key words: intrauterine fetal death; MTHFR; genetic polymorphism

Ginekologia Polska 2019; 90, 2: 76-81

\section{INTRODUCTION}

Intrauterine fetal death (IUFD) is a very traumatic event for the expectant parents. The reason is often unclear, which poses the challenge of identifying it. Generally, the cause of intrauterine fetal death may be qualified as maternal, fetal or placental. Fetal reasons concern mainly multiple pregnancy, intrauterine growth restriction, fetal defects, genetic disorders and fetal hydrops of various etiology. Placental causes include umbilical disorders, preterm placental abruption, preterm premature rupture of membranes, feto-maternal hemorrhage or placental insufficiency. Finally, among some most important maternal reasons of intrauterine fetal death are post-term pregnancy (> 42 gestational week), improperly controlled diabetes and other chronic diseases, such as systemic lupus erythematosus, antiphospholipid syndrome, infections, hypertension, preeclampsia/eclampsia. This group also concerns inherited and acquired thrombophilia as well as disturbances of folate and choline cycle [1-5]. Unfortunately, the reason of intrauterine fetal death remains unknown in $25-60 \%$ cases.

Hiperhomocysteinemia in pregnant patients, apart from increasing significantly the risk of recurrent miscarriage, may also result in development of preeclampsia, fetal hypotrophy, preterm placental abruption, preterm delivery, neural tube defects, cleft palate and intrauterine fetal death. 
5,10-Methylenetetrahydrofolate reductase (MTHFR) is a key enzyme in folate metabolism that carries out the irreversible conversion of 5,10-methylenetetrahydrofolate to 5-methyltetrahydrofolate, thus generating the active form of folate required for remethylation of homocysteine to methionine. MTHFR gene is highly polymorphic and most of the described genetic variants are functional [6-8]. The most commonly described nonsynonymous single-nucleotide polymorphism (SNP) variants are: alanine-to-valine substitution at codon 222 (677C > T, rs1801133), glutamate-to-alanine substitution at codon 429 (1298A > C, rs1801131) and Arg594GIn (1793G > A, rs2274976).

\section{Aim of the study}

The aim of the study was to investigate the association between the three MTHFR SNPs and the IUFD in Polish women, as well as to estimate the effect of haplotypes formed by SNPs localized in the same gene.

\section{MATERIAL AND METHODS}

The patients were recruited in the Department of Perinatology and Women's Diseases of Poznan University of Medical Sciences in years 2009-2015. The Bioethical Committee of Poznan University of Medical Sciences approved the study. Written informed consent was obtained from all the participants.

A total of 476 women were enrolled into the case-control study: 76 patients with at least one intrauterine fetal death after 22 nd gestational week and 400 healthy controls (Tab 1). The inclusion criteria to the study group were as follows: Polish citizenship, Caucasian race, positive history of intrauterine fetal death after $22^{\text {nd }}$ gestational week, unknown reason of intrauterine fetal death, no chronic diseases at patient. The following data was analyzed: age, parity, gestation age at the time of IUFD, obstetrical and general medical history, accompanying obstetrical complications. Women with known reason of IUFD (eg. hypertension, preeclampsia/eclampsia, placental abruption, infec- tious diseases, anemia, fetal defects) were excluded from the study group. Women with antiphospholipid syndrome, anatomical, hormonal, autoimmune, infectious disorders at the moment of joining the study group and thrombotic events or chronic diseases in medical history, also did not qualify for the study.

The control group comprised of healthy women with at least two pregnancies ended with a delivery of healthy newborn at term and no history of pregnancy complications, miscarriage, intrauterine fetal death or preeclampsia. All women from the study and control groups were taking folic acid $400 \mu \mathrm{g}$ per day according to worldwide recommendations as to folate supplementation during pregnancy.

Genomic DNA was extracted from blood cells using QIAamp DNA Blood Mini Kit (Qiagen, Germany). The blood samples (about $5 \mathrm{~mL}$ ) were taken from elbow vein to the Monovete tube at the opportunity of standard lab tests. Three missense single nucleotide change of the MTHFR gene were taken under investigation: $677 C>T$ (rs1801133), $1298 A>C($ rs1801131) and $1793 G>A($ rs2274976). Genotyping was performed using a polymerase chain reaction and restriction fragment length polymorphism (PCR-RFLP) method previously published by Frost et al. (1995), Hanson et al. (2001) and Rady et al. (2002), respectively $[6,8,9]$. The starters used, restriction enzymes and fragment length after hydrolysis are shown in Table 2.

\section{Statistical analysis}

All statistical analyses was performed using R statistical system (version 3.5.0, http://cran.r-project.org). Continuous variables are presented as mean \pm SD and were analyzed by independent ttest. Genotyping success rate yielded 100\% for all the investigated SNPs. Distributions of genotypes were checked with a Hardy-Weinberg equilibrium test.

Two-sided $p$-values $<0.05$ were considered statistically significant. Comparison of genotype frequency differences between groups was performed by unconditional logistic

Table 1. Description of studied polymorphisms

\begin{tabular}{|c|c|c|c|c|}
\hline SNP & Sequence of primers & $\begin{array}{l}\text { PCR product } \\
\text { (bp) }\end{array}$ & Restriction enzyme & Products \\
\hline 677C > T (rs1801133) & $\begin{array}{l}5^{\prime} \mathrm{TGA} \text { AGG AGA AGG TGT CTG CGG GA } 3^{\prime} \\
5^{\prime} \text { AGG ACG GTG CGG TGA GAG TG 3' }\end{array}$ & 198 & $\begin{array}{l}\text { Hinfl } \\
\text { (Eurx) }\end{array}$ & $\begin{array}{c}C C-198 \mathrm{bp} \\
C T-198,175,23 \mathrm{bp} \\
T T-175,23 \mathrm{bp}\end{array}$ \\
\hline $1298 \mathrm{~A}>\mathrm{C}(\mathrm{rs} 1801131)$ & $\begin{array}{c}\text { 5' CTT CTA CCT GAA GAG CAA GTC-3' } \\
\text { 5' CAT GTC CAC AGC ATG GAG-3' }\end{array}$ & 256 & $\begin{array}{l}\text { Mboll } \\
\text { (Eurx) }\end{array}$ & $\begin{array}{c}A A-176,30,28,22 b p \\
A C-204,30,28,22 b p \\
C C-204,30,22 b p\end{array}$ \\
\hline $\begin{array}{l}1793 G>A \\
(r s 2274976)\end{array}$ & $\begin{array}{l}\text { 5'CTC TGT GTG TGT GTG CAT GTG TGC G 3' } \\
\text { 5' GGG ACA GGA GTG GCT CCA ACG CAG G 3' }\end{array}$ & 310 & $\begin{array}{c}\text { Mbil } \\
\text { (Thermo Scientific) }\end{array}$ & $\begin{array}{c}G G-233,77 b p \\
G A-310,233,77 b p \\
A A-310 b p\end{array}$ \\
\hline
\end{tabular}




\begin{tabular}{|c|c|c|c|c|}
\hline Parameter & & $\begin{array}{l}\text { IUFD } \\
(n=76)\end{array}$ & $\begin{array}{c}\text { Control } \\
(n=400)\end{array}$ & $\mathbf{p}$ \\
\hline $\begin{array}{l}\text { Age } \\
\text { (years) }\end{array}$ & $\begin{array}{l}\text { mean } \pm \text { SD } \\
\text { median } \\
\text { min-max }\end{array}$ & $\begin{array}{c}30.46 \pm 4.35 \\
31 \\
20-42\end{array}$ & $\begin{array}{c}30.05 \pm 3.51 \\
30 \\
22-44\end{array}$ & 0.07 \\
\hline $\begin{array}{l}\text { Systolic pressure } \\
(\mathrm{mm} \mathrm{Hg})\end{array}$ & $\begin{array}{c}\text { mean } \pm \text { SD } \\
\text { median } \\
\text { min-max }\end{array}$ & $\begin{array}{c}105.80 \pm 11.55 \\
102.5 \\
90-140\end{array}$ & $\begin{array}{c}107.85 \pm 9.82 \\
110 \\
80-130\end{array}$ & 0.11 \\
\hline $\begin{array}{l}\text { Diastolic pressure } \\
(\mathrm{mm} \mathrm{Hg})\end{array}$ & $\begin{array}{c}\text { mean } \pm \text { SD } \\
\text { median } \\
\text { min-max }\end{array}$ & $\begin{array}{c}66.61 \pm 10.49 \\
60 \\
55-110\end{array}$ & $\begin{array}{c}68.16 \pm 8.70 \\
70 \\
50-95\end{array}$ & 0.17 \\
\hline $\begin{array}{l}\text { Height } \\
(\mathrm{cm})\end{array}$ & $\begin{array}{c}\text { mean } \pm \text { SD } \\
\text { median } \\
\text { min-max }\end{array}$ & $\begin{array}{c}165.84 \pm 8.58 \\
167.0 \\
150-183\end{array}$ & $\begin{array}{c}166.43 \pm 5.41 \\
166.5 \\
150-180\end{array}$ & 0.60 \\
\hline $\begin{array}{l}\text { Weight } \\
(\mathrm{kg})\end{array}$ & $\begin{array}{c}\text { mean } \pm \text { SD } \\
\text { median } \\
\text { min-max }\end{array}$ & $\begin{array}{c}62.01 \pm 9.91 \\
61 \\
44-99\end{array}$ & $\begin{array}{c}60.25 \pm 9.64 \\
58 \\
45-110\end{array}$ & 0.15 \\
\hline $\begin{array}{l}\text { BMl } \\
\left(\mathrm{kg} / \mathrm{m}^{2}\right)\end{array}$ & $\begin{array}{c}\text { mean } \pm S D \\
\text { median } \\
\text { min-max }\end{array}$ & $\begin{array}{c}22.58 \pm 3.59 \\
21.67 \\
18.03-38.67\end{array}$ & $\begin{array}{c}21.74 \pm 3.21 \\
20.90 \\
16.53-38.57\end{array}$ & 0.04 \\
\hline IUFD & $\begin{array}{c}\text { one } \\
\text { two or more }\end{array}$ & $\begin{array}{c}69(90.79 \%) \\
7(9.21 \%)\end{array}$ & $\begin{array}{l}0 \\
0\end{array}$ & - \\
\hline Gestational week of IUFD & $\begin{array}{l}\text { mean } \pm \text { SD } \\
\text { median } \\
\text { min-max }\end{array}$ & $\begin{array}{c}30.02 \pm 4.92 \\
30 \\
22-40\end{array}$ & - & - \\
\hline
\end{tabular}

regression using the SNPassoc package [10]. The Bonferroni method was used to adjust for multiple comparisons ( $p=0.017$ for three SNPs).

Distribution of haplotypes in the study group was compared with chi-squared tests in Haploview software version 4.2 (https://www.broadinstitute.org/haploview/haploview). Permutation tests were used to correct multiple testing errors with 1000 simulations.

\section{RESULTS}

\section{Clinical data analysis}

The clinical characteristics of patients enrolled in this study were summarized in Table 2 . The mean age of case and control groups was $30.46 \pm 4.35$ years, (median 31 years, range: $20-42$ years) and $30.05 \pm 3.51$ years, (median 30 years, range: $22-44$ years), respectively $(p=0.07)$. No statistically significant difference was observed in blood pressure, height or weight between the two groups. The study group had a statistically higher BMI compared to the control group (IUFD: $22.58 \pm 3.59$ vs. $21.57 \pm 3.23 \mathrm{~kg} / \mathrm{m} 2, \mathrm{p}=0.04$ ). 69 patients $(90.79 \%)$ had one IUFD episode while 2 or more such episodes occurred in 7 patients (9.21\%). The mean gestational age of IUFD was $30.02 \pm 4.95$ gestational week.

\section{Genetic analysis}

The genotype and haplotype frequencies of the three polymorphisms were in accordance with the Har-
dy-Weinberg equilibrium in both: the case and the control groups. The distribution of the genotypes and their ORs for association with IUFD risk are shown in Table 3. No significant association was found between the presence of MTHFR rs 1801133 or rs2274976 polymorphism and the incidence of IUFD overall. The biggest statistical difference was observed for rs1801131 $A>C$ polymorphism. Best-fit models for this SNP were dominant $(\mathrm{OR}=0.61,95 \% \mathrm{Cl}=0.36-1.02$; $p=0.05 ; \mathrm{AIC}=418.3)$ and overdominant $(\mathrm{OR}=0.61,95 \%$ $\mathrm{Cl}=0.37-1.00 ; p=0.05 ; \mathrm{AIC}=418.2$ ), also after Bonferroni correction $p_{\text {corr }}=0.15$.

We have not found any difference in frequencies for investigated MTHFR gene polymorphism between patients with one or two and more IUFDs. For $667 C>T$ polymorphism in the seven women that had two or more IUFD, five had 677CC genotype, one 677CT and one 677TT. In turn, their $1298 \mathrm{~A}>\mathrm{C}$ genotype was as follows: two with $1298 \mathrm{AA}$ (28.6\%), four with $1298 A C(57.1 \%)$ and one woman with $1298 C C$ (14.3\%). All seven women with two or more IUFDs had $1793 G G$ genotypes.

\section{Haplotype analysis}

The prevalence of MTHFR haplotype frequency in controls and women with intrauterine fetal death is presented in Table 4. Haplotype analysis of three (rs1801133, rs1801131, rs2274976) and two (rs1801133, rs1801131) MTHFR loci revealed respectively four and three haplotypes with a fre- 


\begin{tabular}{|c|c|c|c|c|c|}
\hline Genotypes & $\begin{array}{l}\text { IUFD } \\
\text { n (\%) }\end{array}$ & $\begin{array}{c}\text { Control } \\
\text { n (\%) }\end{array}$ & OR $(95 \% \mathrm{Cl})$ & $\mathbf{p}$ & AIC \\
\hline \multicolumn{6}{|l|}{$677 C>T($ rs1801133) } \\
\hline CC & $42(55.3)$ & $201(50.2)$ & 1.00 & \multirow{3}{*}{0.22} & \multirow{3}{*}{421.0} \\
\hline $\mathrm{CT}$ & $24(31.6)$ & $164(41.0)$ & $1.43(0.83-2.46)$ & & \\
\hline TT & $10(13.2)$ & $35(8.8)$ & $0.73(0.34-1.59)$ & & \\
\hline Dominant (CC vs. $C T+T T)$ & $34(44.7)$ & $199(49.8)$ & $1.22(0.75-2.00)$ & 0.42 & 421.4 \\
\hline Recessive $(C C+C T$ vs. $T T)$ & $66(86.8)$ & $365(91.2)$ & $0.63(0.30-1.34)$ & 0.25 & 420.7 \\
\hline Overdominant $(C C+T T$ vs. $C T)$ & $52(68.4)$ & $236(59.0)$ & $1.51(0.89-2.54)$ & 0.12 & 419.6 \\
\hline log-Additive $(0,1,2)$ & $76(16.0)$ & $400(84.0)$ & $1.01(0.70-1.47)$ & 0.94 & 422.0 \\
\hline Minor allele frequency & $44(28.9)$ & $234(29.2)$ & $1.01(0.69-1.49)$ & 0.94 & 840.1 \\
\hline \multicolumn{6}{|l|}{$1298 \mathrm{~A}>\mathrm{C}(\mathrm{rs} 1801131)$} \\
\hline $\mathrm{AA}$ & $25(32.9)$ & $179(44.8)$ & 1.00 & \multirow{3}{*}{0.12} & \multirow{3}{*}{419.8} \\
\hline$A C$ & $42(55.3)$ & $172(43.0)$ & $0.57(0.33-0.98)$ & & \\
\hline $\mathrm{CC}$ & $9(11.8)$ & $49(12.2)$ & $0.76(0.33-1.73)$ & & \\
\hline Dominant $(A A$ vs. $A C+C C)$ & $51(67.1)$ & $221(55.2)$ & $0.61(0.36-1.02)$ & 0.05 & 418.3 \\
\hline Recessive $(A A+A C$ vs. $C C)$ & $67(88.2)$ & $351(87.8)$ & $1.04(0.49-2.22)$ & 0.92 & 422.0 \\
\hline Overdominant $(A A+C C$ vs. $A C)$ & $34(44.7)$ & $228(57.0)$ & $0.61(0.37-1.00)$ & 0.05 & 418.2 \\
\hline log-Additive $(0,1,2)$ & $76(16.0)$ & $400(84.0)$ & $0.78(0.55-1.12)$ & 0.18 & 420.2 \\
\hline Minor allele frequency & $60(39.5)$ & $270(33.8)$ & $1.28(0.91 .83)$ & 0.18 & 838.3 \\
\hline \multicolumn{6}{|l|}{ 1793G > A (rs2274976) } \\
\hline GG & $69(90.8)$ & $368(92.0)$ & 1.00 & \multirow{3}{*}{0.70} & \multirow{3}{*}{423.5} \\
\hline GA & $7(9.2)$ & $31(7.8)$ & $0.83(0.35-1.96)$ & & \\
\hline $\mathrm{AA}$ & $0(0.0)$ & $1(0.2)$ & 0.00 & & \\
\hline Dominant (GG vs. GA + AA) & $7(9.2)$ & $32(8.0)$ & $0.86(0.36-2.02)$ & 0.73 & 421.9 \\
\hline Recessive (GG + GA vs. $A A)$ & $76(100.0)$ & $399(99.8)$ & & 1.00 & 421.7 \\
\hline Overdominant $(G G+A A$ vs. $G A$ & $69(90.8)$ & $369(92.2)$ & $0.83(0.35-1.96)$ & 0.67 & 421.9 \\
\hline log-Additive $(0,1,2)$ & $76(16.0)$ & $400(84.0)$ & $0.89(0.39-2.05)$ & 0.70 & 422.0 \\
\hline Minor allele frequency & $7(4.6)$ & $33(4.1)$ & $0.89(0.39-2.05)$ & 0.79 & 840.0 \\
\hline
\end{tabular}

\begin{tabular}{|c|c|c|c|c|c|c|c|}
\hline \multicolumn{3}{|c|}{ Haplotype } & \multirow{2}{*}{$\begin{array}{l}\text { Frequency } \\
\text { (overall) }\end{array}$} & \multirow{2}{*}{$\begin{array}{c}\text { Frequency } \\
\text { (case,control) }\end{array}$} & \multirow{2}{*}{$x^{2}$} & \multirow{2}{*}{ p value } & \multirow{2}{*}{ p value } \\
\hline rs1801133 & rs1801131 & rs2274976 & & & & & \\
\hline C & A & G & 0.361 & $0.316,0.370$ & 1.627 & 0.2022 & 0.5840 \\
\hline C & C & G & 0.305 & $0.349,0.296$ & 1.658 & 0.1979 & 0.5640 \\
\hline T & A & G & 0.292 & $0.289,0.292$ & 0.006 & 0.9400 & 1.0000 \\
\hline C & C & A & 0.042 & $0.046,0.041$ & 0.073 & 0.7867 & 0.9910 \\
\hline C & A & & 0.361 & $0.316,0.370$ & 1.627 & 0.2022 & 0.5160 \\
\hline C & C & & 0.347 & $0.395,0.338$ & 1.848 & 0.1741 & 0.4750 \\
\hline$T$ & A & & 0.292 & $0.289,0.292$ & 0.006 & 0.940 & 1.0000 \\
\hline
\end{tabular}

${ }^{*} p$ value calculated using permutation test and a total of 1000 permutations

quency of more than 1\%. Higher occurrence of CAG haplotype (containing all non-mutated variants) was observed in the control group (0.37 vs. 0.32 in IUFD group, $\mathrm{p}_{\text {corr }}=0.584$ ).
The lowest overall $p$-values, namely $p=0.20$ and $p_{\text {corr }}=0.56$, were observed for a three-locus haplotype CCG and two-locus - the MTHFR haplotype CC $\left(p=0.17\right.$ and $\left.p_{\text {corr }}=0.48\right)$. 
These haplotypes were observed more frequently in the IUFD group than controls ( 0.35 and 0.40 vs. 0.30 and 0.34 at controls).

\section{DISCUSSION}

Folate and choline play a pivotal role in many cellular processes including DNA synthesis, methylation and homocysteine metabolism. Folate and choline as well as many reactions that depend on their level have been shown to be essential for proper intrauterine fetal development. Several pregnancy conditions have been indicated to correlate with lower MTHFR activity, with folate and choline deficiency and with several MTHFR and PEMT genetic polymorphisms [11, 12]. The presence of MTHFR gene polymorphism causes mild hypercoagulability while disturbances in coagulation cascade during pregnancy may lead to IUFD. Thus, IUFD may be a result of specifically unfavorable MTHFR gene polymorphism, especially when combined with some harmful environmental factors [13-15].

It is worth to underline that as far as we know, our study is first in Poland to investigate the association of SNPs and intrauterine fetal death in the second part of pregnancy.

The present study has not revealed any significant role of $677 C>T$ or $1793 G>A$ MTHFR gene polymorphism in the etiology of intrauterine fetal death. Yet, the most important observation concerns the role of $1298 \mathrm{~A}>$ C polymorphism, which points to increased risk of obstetrical complication in the population of Polish women (genotype 1298 AC: 55.3 vs. $43.0 \%$ in the control group, $\mathrm{OR}=0.61$, $p=0.05$. Mutated allele $1298 \mathrm{C}: 39.5$ vs. $33.8 \%$ in the control group, $\mathrm{OR}=1.28, p=0.18$ ).

In the study of Nurk et al. correlation between Leiden mutation, MTHFR gene polymorphism and some obstetrical complications was analyzed. The research involved 5874 women from Norwegian population. The presence of factor Leiden was correlated with increased rate of preeclampsia $(O R=1.63)$, small gestational weight $(O R=1.34)$ and IUFD $(\mathrm{OR}=2.20)$. Variant allele for the $677 \mathrm{C}>$ TMTHFR polymorphism was found to strengthen the association between FVL and stillbirth (OR 3.34) [16].

Silver et al. analyzed a large population-based case-control study of stillbirths (488 stillbirths and 1342 live birth mothers and 405 stillbirths and 990 live birth fetuses) testing for factor V Leiden, prothrombin 20210G > A, MTHFR 677C > T and 1298A > C, and plasminogen activating inhibitor (PAI)-1 4G/5G mutations in mother and fetus. Maternal factor $V$ Leiden was weakly associated with stillbirth but most maternal and fetal thrombophilia, including 677C > T and 1298A > C MTHFR polymorphism, were not associated with stillbirth [17].

The aim of the study of Murakami et al. was to assess the influence of MTHFR genetic variants on the homocyst- eine serum concentration during early pregnancy. The study involved 816 women between 6 and 12 gestational week. Homocysteine concentration was significantly higher in women with 677TT ( $p<0.0001)$ genotype. Moreover, women with hyperhomocysteinemia in the further course of pregnancy developed preeclampsia $(p<0.01)$ and IUFD $(p<0.05)$ more frequently [18].

On the other hand, the study of Hefler et al. revealed no correlation between genetic variants resulting in thrombophilia (factor V Leiden, H1299R factor V gene, 20210G > A factor II gene, V34L factor XIII, 677C > T and 1298A>C MTHFR gene, 455G > A beta-fibrinogen gene, 4G/5G PAl-1, L33P GPIIla, C282Y HFE, R3500Q apolipoprotein B and E2/E3/E4 apolipoproteins) and increased risk of IUFD. A total of 94 women with IUFD and 94 healthy women with a positive history of at least one normal pregnancy with live birth at term and negative history of IUFD were enrolled into the study [19].

There are also some reports indicating the role of co-existence of $677 C>T$ and $1298 A>C$ MTHFR gene polymorphisms in the etiology of obstetrical complications. A proportion of $46 \%$ of 113 Turkish women group with obstetrical complications were carriers of $677 C T$ and 1298AC MTHFR heterozygotic genotypes [20]. There are also some suggestions that the presence of two mutated genotypes $677 C>T$ and 1298 A > C of MTHFR gene may lead to fetal demise at early stages of pregnancy [21,22].

The most essential is that the analysis of MTHFR genetic polymorphism could also identify the risk group of IUFD. In light of previous observations that MTHFR polymorphism predisposes to very mild thrombophilia, LMWH prophylaxis could be considered for women in IUFD risk group. Such recommendation would be in line with the findings of Aracic et al. who showed that LMWH prophylaxis has reduced the incidence of fetal growth restriction (FGR), preterm birth (PTB) and IUFD in women carrying the MTHFR, ACE and PAl-1 genetic variants [23]

\section{CONCLUSIONS}

In conclusion, our results showed no significant relationship between MTHFR 677C > T and 1793G > A genotypes distribution among patients with IUFD and controls. The 1298 A > C variant showed a slightly higher but statistically insignificant prevalence of IUFD compared to the controls in Polish population.

On the basis of obtained results it might be suggested that there is no influence of investigated polymorphisms on the risk of intrauterine fetal death in Polish population. But of course, further studies on a larger population are needed. To better understand the pathobiology of IUFD, we need to know more about interactions of polymorphic variants with each other and with the environment. It is also worth to underline that probable role of MTHFR gene 
polymorphisms in the etiology of intrauterine fetal death may be a result of hyperhomocysteinemia caused by these genetic variants [24-26].

\section{REFERENCES}

1. Lamont K, Scott NW, Jones GT, et al. Risk of recurrent stillbirth: systematic review and meta-analysis. BMJ. 2015; 350: h3080, doi: 10.1136/bmj. h3080, indexed in Pubmed: 26109551.

2. Man J, Hutchinson JC, Heazell AE, et al. Stillbirth and intrauterine fetal death: role of routine histopathological placental findings to determine cause of death. Ultrasound Obstet Gynecol. 2016; 48(5): 579-584, doi: 10.1002/uog.16019, indexed in Pubmed: 27781319.

3. Stillbirth Collaborative Research Network Writing Group. Association between stillbirth and risk factors known at pregnancy confirmation. JAMA. 2011;306(22): 2469-2479, doi: 10.1001/jama.2011.1798, indexed in Pubmed: 22166606

4. Man J, Hutchinson JC, Ashworth $M$, et al. Stillbirth and intrauterine fetal death: role of routine histological organ sampling to determine cause of death. Ultrasound Obstet Gynecol. 2016; 48(5): 596-601, doi: 10.1002/uog.16020, indexed in Pubmed: 27781316.

5. Barut MU, Bozkurt M, Kahraman M, et al. Thrombophilia and Recurrent Pregnancy Loss: The Enigma Continues. Med Sci Monit. 2018; 24: 4288-4294, doi: 10.12659/MSM.908832, indexed in Pubmed: 29932168.

6. Kim JiY, Kim JiW, Sung SeRa, et al. Impact of RFC1, MTHFR, and MTHFD1 polymorphism on unexplained pregnancy loss (UPL): comparative analysis of maternal and fetal components using mother-abortus paired samples. Eur J Obstet Gynecol Reprod Biol. 2018; 231: 152-157, doi: 10.1016/j.ejogrb.2018.09.017, indexed in Pubmed: 30388610.

7. van der Put NM, Gabreëls F, Stevens EM, et al. A second common mutation in the methylenetetrahydrofolate reductase gene: an additional risk factor for neural-tube defects? Am J Hum Genet. 1998; 62(5): 1044-1051, doi: 10.1086/301825, indexed in Pubmed: 9545395.

8. Frosst $\mathrm{P}, \mathrm{Blom} \mathrm{HJ}$, Milos $\mathrm{R}$, et al. A candidate genetic risk factor for vascular disease: a common mutation in methylenetetrahydrofolate reductase. Nat Genet. 1995; 10(1): 111-113, doi: 10.1038/ng0595-111, indexed in Pubmed: 7647779.

9. Hanson NQ, Aras O, Yang F, et al. C677T and A1298C polymorphisms of the methylenetetrahydrofolate reductase gene: incidence and effect of combined genotypes on plasma fasting and post-methionine load homocysteine in vascular disease. Clin Chem. 2001; 47(4): 661-666, indexed in Pubmed: 11274015.

10. González JR, Armengol L, Guinó E et al., (2014). SNPassoc: SNPs-based whole genome association studies. R package version 1.9-2. https:// CRAN.R-project.org/package $=$ SNPassoc.

11. Drews K, Różycka A, Barlik M, et al. Polymorphic variants of genes involved in choline pathway and the risk of intrauterine fetal death. Ginekol Pol. 2017; 88(4): 205-211, doi: 10.5603/GP.a2017.0039, indexed in Pubmed: 28509322.

12. Seremak-Mrozikiewicz A, Barlik M, Różycka A, et al. Importance of polymorphic variants of phosphatidylethanolamine $\mathrm{N}$-methyltransferase (PEMT) gene in the etiology of intrauterine fetal death in the Polish population. Eur J Obstet Gynecol Reprod Biol. 2018; 231:43-47, doi: 10.1016/j. ejogrb.2018.10.021, indexed in Pubmed: 30321787.
13. Turgal M, Gumruk F, Karaagaoglu E, et al. Methylenetetrahydrofolate Reductase Polymorphisms and Pregnancy Outcome. Geburtshilfe Frauenheilkd. 2018; 78(9): 871-878, doi: 10.1055/a-0664-8237, indexed in Pubmed: 30258247.

14. Simonidesova M, Simko J, Holoman K. Defects of genes encoding inhibitors of coagulation and their application in early miscarriage aetiology. BratisI Lek Listy. 2014; 115(11): 730-735, indexed in Pubmed: 25428544.

15. Torabi $\mathrm{R}$, Zarei $\mathrm{S}$, Zeraati $\mathrm{H}$, et al. Combination of thrombophilic gene polymorphisms as a cause of increased the risk of recurrent pregnancy loss. J Reprod Infertil. 2012; 13(2): 89-94, indexed in Pubmed: 23926530.

16. Nurk E, Tell GS, Refsum H, et al. Factor $V$ Leiden, pregnancy complications and adverse outcomes: the Hordaland Homocysteine Study. QJM. 2006; 99(5): 289-298, doi: 10.1093/qjmed/hcl040, indexed in Pubmed: 16613994.

17. Silver RM, Saade GR, Thorsten V, et al. Factor V Leiden, prothrombin G20210A, and methylene tetrahydrofolate reductase mutations and stillbirth: the Stillbirth Collaborative Research Network. Am J Obstet Gynecol. 2016; 215(4): 468.e1-468.e17, doi: 10.1016/j.ajog.2016.04.026, indexed in Pubmed: 27131585.

18. Murakami S, Matsubara N, Saitoh M, et al. The relation between plasma homocysteine concentration and methylenetetrahydrofolate reductase gene polymorphism in pregnant women. J Obstet Gynaecol Res. 2001; 27(6): 349-352, indexed in Pubmed: 11794822.

19. Hefler L, Jirecek S, Heim K, et al. Genetic polymorphisms associated with thrombophilia and vascular disease in women with unexplained late intrauterine fetal death: a multicenter study. J Soc Gynecol Investig. 2004; 11(1): 42-44, indexed in Pubmed: 14706682.

20. Aytekin E, Ergun SG, Ergun MA, et al. Evaluation of GenoFlow Thrombophilia Array Test Kit in its detection of mutations in Factor $V$ Leiden (G1691A), prothrombin G20210A, MTHFR C677T and A1298C in blood samples from 113 Turkish female patients. Genet Test Mol Biomarkers. 2014; 18(11): 717-721, doi: 10.1089/gtmb.2014.0143, indexed in Pubmed: 25153695.

21. Le Marchand L, Donlon T, Hankin JH, et al. B-vitamin intake, metabolic genes, and colorectal cancer risk (United States). Cancer Causes Control. 2002; 13(3): 239-248, indexed in Pubmed: 12020105.

22. Zetterberg $H$, Regland $B$, Palmér $M$, et al. Increased frequency of combined methylenetetrahydrofolate reductase $\mathrm{C} 677 \mathrm{~T}$ and $\mathrm{A} 1298 \mathrm{C}$ mutated alleles in spontaneously aborted embryos. Eur J Hum Genet. 2002; 10(2): 113-118, doi: 10.1038/sj.ejhg.5200767, indexed in Pubmed: 11938441.

23. Aracic N, Roje D, Jakus IA, et al. The Impact of Inherited Thrombophilia Types and Low Molecular Weight Heparin Treatment on Pregnancy Complications in Women with Previous Adverse Outcome. Yonsei Med J. 2016; 57(5): 1230-1235, doi: 10.3349/ymj.2016.57.5.1230, indexed in Pubmed: 27401656.

24. Jin $\mathrm{H}$, Cheng $\mathrm{H}$, Chen $\mathrm{W}$, et al. An evidence-based approach to globally assess the covariate-dependent effect of the MTHFR single nucleotide polymorphism rs1801133 on blood homocysteine: a systematic review and meta-analysis. Am J Clin Nutr. 2018; 107(5): 817-825, doi: 10.1093/ajen/nqy035, indexed in Pubmed: 29722849.

25. Ibrahim S, Maqbool S, Azam M, et al. CBS mutations and MTFHR SNPs causative of hyperhomocysteinemia in Pakistani children. Mol Biol Rep. 2018; 45(3): 353-360, doi: 10.1007/s11033-018-4169-9, indexed in Pubmed: 29600437.

26. Li A, Shi Y, Xu L, et al. A possible synergistic effect of MTHFR C677T polymorphism on homocysteine level variations increased risk for ischemic stroke. Medicine (Baltimore). 2017; 96(51): e9300, doi: 10.1097/MD.0000000000009300, indexed in Pubmed: 29390494. 